\title{
TYPES OF SECURITY EDUCATION IN POLAND. SELECTED EXAMPLES
}

\author{
Marlena ZADOROŻNA, M.A. \\ m.zadorozna@akademia.mil.pl \\ Faculty of National Security \\ War Studies University, Warsaw, Poland
}

\begin{abstract}
The purpose of the article is to examine selected examples of types of security education in Poland. At the beginning of the 20th century, national security was centered on military and political aspects, but recent decades have seen the successive shifting of the focus from the military-political plane of security to other areas. It seems that educational concepts adapt to emerging challenges. This thesis is confirmed by the concept of global education, the idea of military classes, as well as the military training of pro-defensive organisations within the framework of the Passport Program. All of these educational concepts were covered in the study. One of the most important conclusions of the article will be to emphasise the correlation between the evolution of the understanding of security, the transformation of threats and changes in the field of educational concepts.
\end{abstract}

Keywords: security education, global education, military classes, Passport Program, prodefensive organisations, the Republic of Poland, security studies

\section{Introduction}

The purpose of the article is to examine selected examples of types of security education in Poland. It appears that current world changes have prompted a reflection on education as a way of resisting threats. The authors of the National Security Strategy of the Republic of Poland (2014, pp. 39, 52-53) drew attention 
to the importance of security education. They not only stressed the need to raise public awareness of understanding security threats, but also indicated the need to shape competences that allow them to respond. They signalled need to intensify educational activities for security requirement, including greater emphasis on the quality of the education system in areas which are essential for the security of the state and its citizens.

The shaping of the concept of security education was accompanied by a reorientation in the perception of security itself, based on successive shifting of the focus from the military-political plane of security to other areas. This reorientation was contributed by a British researcher called Barry Buzan. After the Cold War, he distinguished five fundamental areas of security - military, political, social, economic and ecological (Buzan, Wæver and de Wilde 1998). The scope of security, as well as the current catalogue of areas of security were clearly broadened. In the traditional approach, security was associated mainly with the military ability of the state to repulse armed aggression. At present, human and non-state collective units are of great importance in security analyses. This demilitarised defining of security was characteristic of representatives of the Copenhagen School; however, this does not mean that military-defensive issues have been excluded from the semantic area of security. It rather indicates its wider, multidimensional identification.

The first part of the study is an introduction to the subject of education in the field of security and its evolution, while the following parts of the article discuss various examples of types of security education in Poland. One of the most important conclusions of the article will be to emphasise the correlation between the evolution of the understanding of security, the transformation of threats and changes in the field of educational concepts. It should be noted that the study used theoretical research methods, including text analysis, comparison, synthesis and inference.

\section{Evolution of security education}

At the beginning of the 20th century, national security was centered on military and political aspects, but recent decades have seen changes in the nature of threats. For example, the First World War turned out to be a clash of the potentials and 
possibilities of militant parties, not of the troops themselves. Military planning has made it necessary to take into account civil (especially economic and social) factors. Subsequent Polish strategic documents emphasise the importance of non-military threats and indicate the political, social, economic, ethnic, as well as the religious background of possible crises. The emergence of new threats and challenges were undermined by the beginning of the global war on terror. In the National Security Strategy of the Republic of Poland of July 22, 2003, the focus shifted from the classic threats (such as armed invasion) to atypical threats (initiated by non-state actors difficult to identify). At the same time, it was remembered that it was necessary to monitor the situation with a view to the rebirth of traditional threats. Jacek Reginia-Zacharski (2013, p. 70) notes that the broader perspective of strategic reflection corresponded to the diagnosis of threats and challenges, whose nature from the military sphere has been shifted towards non-military issues. Furthermore, modern threats are notable for their dual nature and, as a consequence, their individual meanings do not appear separately. An example is a terrorist attack whose decision-making centre is located outside the target country. Reginia-Zacharski (2013, p. 63) points out that another category should be added to the classical division of threats into internal and external threats - cross-border threats. All threats can also be grouped in terms of intensity. Each classification criterion will have an impact on the definitione of state policy goals.

In the last few decades, there has been a total and dynamic remodeling of the international environment. The factors conditioning the security of the Republic of Poland underwent profound changes. The dynamics of changes and the difficult to predict direction of the processes that are taking place determine the planning possibilities. The pace of changes in the state security environment makes it difficult to forecast, and the assumed scenarios of events are subject to high risk. Forecasting is additionally hampered by a permanent technological revolution. However, security analysts and policy-makers are required to develop strategies that take into account the use of development opportunities, risk minimalisation, threat prevention and effective crisis management. Security management itself must be a continuous, constantly modified and updated proces. Further, along with the etymological evolution of security, educational activites in this area are changing. It seems that educational concepts adapt to emerging challenges. In the last years of the 20th century, the idea of security education began to 
crystallise. Janusz Świniarski (2011, pp. 20-21) notes that in Poland, the concept of 'security education' appeared in 1994 during the research conducted at the National Defence Univeristy and it became competitive for predominant names of intentional educational activities, such as military training, the defensive preparation of society and defensive education. The first of these functioned as a teaching subject introduced into Polish schools by a decree in 1946 and was implemented up to 1967. Over time, defensive adoption included, among others, civil defence, civil protection against weapons of mass destruction, fire protection, topography, sanitary training, shooting training, as well as military drill and regulations. The subject covering the above content was removed from high schools in 2012. It can therefore be concluded that the beginnings of this activity were related to defensive education. Contemporary education for security does, however, go beyond defence.

In line with this approach, some scholars treat defensive education and security education separately, stressing the semantic differences between them (Zalewski 2001, pp. 41-42; Konopka 2013, p. 112). In this context, defensive education may address counteracting threats, while education for security will be associated with responding to challenges that may be threats. Meanwhile, others are looking for common points in both categories, referring to the evolution of the understanding of security itself, i.e. evolution from strictly military to multifaceted identification. According to their approach, education for security can be considered as broadening defensive education with a multi-faceted perspective (Drabik 2014, pp. 48-50). Interestingly, at the beginning of the 21st century, Jerzy Kunikowski (2000, p. 32) claimed that defensive education gives way to security education. In retrosepct, this observation turns out to be right. More and more attention in the field of security is devoted to challenges, which is evidenced by the evolution of Polish strategic documents. Contemporary perception of security education undeniably goes beyond the framework of formal education. Security education is part of a multidimensional educational proces, a component of all activities which are shaping attitudes and skills essential for ensuring security. 


\section{Global education for security}

One of the challenges that Polish security analysts met in the first years of the 21 st century was the challenge resulting from the migratory pressure related to the broadening of unstable and dysfunctional areas (Reginia-Zacharski 2013, pp. 70-71; Domalewska 2018, p. 251). In the context of this challenge, global education becomes particularly important. Global education is a transformative learning process which is required to move to a model of partnership between people, cultures and religions. This process is an education perpective that has arisen because of the fact that contemporary poeple live in non-traditional circumstances, as part of an increasingly globalised world. Global education offers a way to make changes at local levels that may influence the world - it promotes active participation in a globalised world and underlines the importance of the decisions of individuals at the local level. One of the consequences of global education should be the creation of global citizens who can take responsibility for their actions and contribute to a more peaceful world (ed. Carvalho da Silva 2008; ed. Quittner and Sturak 2008). According to the Ministry of Foreign Affairs of the Republic of Poland, the task of global education is to explain the problems of development of the modern world and to indicate the factors shaping international development. Global education refers, inter alia, to the situation in developing countries and countries that undergo systemic transformation. In addition, the process helps to understand the global interdependencies between the societies of developed and developing countries. As a result, global education should lead to a personal commitment to fight poverty worldwide (Ministry of Foreign Affairs of the Republic of Poland n.d.). The Ministry of Foreign Affairs has supported Polish NGOs since 2005, local governments and educational institutions involved in the implementation of global education issues in public debate and Polish schools. This support takes, among others, the following forms:

- cooperation with the media, co-production of radio programmes and documentary films;

- projects implemented by social organisations and educational institutions;

- photo exhibitions;

- international meetings and conferences. 
On May 26, 2011, an Agreement on Supporting the Development of Global Education in Poland was signed by the Ministry of Foreign Affairs, the Ministry of National Education and the Zagranica Group, which is an association of Polish non-governmental organisations involved in international development cooperation, supporting humanitarian aid and democracy. Implementation of the agreement involved non-governmental organisations, government and local government institutions, teachers and academic experts (Polska Pomoc n.d.). One of the members of the Zagranica Group is the Polish Humanitarian Action (PAH) that works mainly with schools at every stage of education. PAH offers ready ideas, scenarios (debates, field games, information campaigns, and fundraising events), substantive publications and other free materials. The organisation also creates e-learning courses and videos available on the YouTube channel (Polish Humanitarian Action n.d.).

The genesis of global education reached the Europe-wide Global Education Congress in Maastricht (2002), attended not only by educationalists, but also by government representatives from over fifty countries. The participating delegations agreed that the mentioned learning process „is essential for strengthening public support for spending on development co-operation" (eds O'Loughlin and Wegimont 2003, p. 2). The main dimensions of global education include: Education for Sustainability, Human Rights Education, Development Education, Intercultural Education and Education for Peace and Conflict Prevention. All of them should be part of the Education for Citizenship, as The Council of Europe's North-South Centre definition of global education states (eds O'Loughlin and Wegimont 2003, p. 3). To conclude, global education goals are in harmony with the shaping of security policy, while security education becomes the task of a global society.

\section{Defence potential of military classes}

In Polish high schools, there are so-called military classes which carry out broadly defined security education and, thereby, the programmes of these classes are enriched with issues related to the Polish army, the defence of the country, and the evolution of patriotric attitudes. Military classes unite enhusiasts, practitioners 
and theoreticians, teachers and students, who, thanks to their activities, integrate with the local environment by shaping civil and prosocial attitudes. These classes were created pursuant to the agreement on cooperation between the Minister of National Defence and the Minister of National Education in the field of didacticeducational, scientific and organisational-logistics activities, signed on May 26, 1994, as well as the decision of the Minister of National Defence of 30 June 1999 on conducting an experiment in the field of youth defence education (Porozumienie 1994; Decyzja nr 126/MON 1999).

It should be noted that similar initiatives have been undertakien in the past in the field of patriotic youth education. The pre-war Corps of Cadets were established by a decision of the state authorities, and their students fought in the name of an independent Poland. Another example is provided by the Military High Schools created in the 1980s to suplement huge gaps in the number of candidates for higher military education. In both cases, experienced military officers on active duty were responsible for military training, and training plans were developed by the relevant military authorities. In today's military classes, quasi military training is conducted, which undoubtedly becomes the premise for initiating changes (Depczyński 2013, pp. 87-88).

Currently, about 50,000 students are taught in uniformed classes throughout Poland. The uniformed classes, however, include not only classes with a military profile, but also police and firefighters. Importantly, the curriculum of military classes and the number of hours spent on military education are varied. Not all schools, due to their location, have the possibility of regular cooperation with military units. Education in military classes looks different in school, which works perfectly with the neighboring military unit every day, and differently in an area where there is no army at all. Then, organising a visit to the unit becomes a significant undertaking. Among other things, in order to unify military teaching, the leadership of the Ministry of National Defencse (MON) decided to change this situation. In September 2017, a pilot programme for upper secondary schools with uniformed classes began. The Ministry of National Defence issued letters to the school directors encouraging participation in the project. As a result, students can take part in military activities more often, and, as graduates, they 
will gain preferences for admission to the $\operatorname{army}^{1}$ (Glińska 2017). The pilot project is conducted in the form of a pedagogical experiment in selected schools with military-style classes. The education will last for two years and, thereby, the subject of military education includes 185 teaching hours. Students attend theoretical and practical classes, take part in classes with military equipment, and participate in training organised by military units and non-governmental organisations. A few days' training camp on a military range was also planned. An additional 30 hours of lessons should be devoted to self-study - the e-learning platform will serve this purpose (Glińska 2017; Urych 2017, p. 47). At this point, it is worth mentioning the former Military High Schools again, in the framework of which, during the summer holidays, compulsory training camps and scientific outgoing sessions on military training grounds were organised for the youth (Depczyński 2013, p. 88; Kryściak 2013, p. 61).

Ilona Urych notes that military grade students become more interested in the issues of state defence, are more involved in social activities and school life, and they are more physically fit. Urych (2016, p. 124) points out, „pupils of the military classes are particularly interested in the subject of widely understood uniformed services, with particular emphasis on military action, including border police, special forces, and also, to a lesser extent, the police and the fire brigade". Students are also interested in modern military equipment and combat operations. They participate in classes in the field of tactics, drill, training, shooting, topography, self-defence and marches of orientation. These types of activity develop the defence potential of young people. It may turn out that students of military classes will join the ranks of people involved in the implementation of the state's defence policy (Kanarski et al. 2014, p. 77; Urych 2018, p. 44). Creating military classes is

1 In May 2017, a representative of the Office for Defence Affairs at the Ministry of National Defence announced that during the course of learning, students would be able to consult representatives of military supplementary commands (for instance, regarding the possibility of being admitted to military service). Then, graduates from schools participating in the Ministry of National Defence project would be able to undergo a few-weeks' military preparatory training, after which they would take an oath and be transferred to the reserve. As reservists, they would have priority in applying for professional military service as well as territorial defence forces. 
synonymous with creating the potential of trained personnel reserves ${ }^{2}$. Due to the importance of this problem, the functioning of these classes is the subject of many studies.

\section{Military training of pro-defensive organisations}

One of the types of short military training is the Passport Program for cooperation of sub-units of pro-defensive organisations with military units of the Armed Forces of the Republic of Poland. In other words, raising the level of training of the components of pro-defensive organisations should improve their ability to cooperate with military units of the Armed Forces. The use of the defence potential of non-governmental organisations serves to support the Polish defence system. The training process lasts a year and is supported by the Ministry of National Defence. The objectives of the program include:

- preparing the components of defence sub-bands to cooperate with military units in the field of training, and selected areas of crisis and combat tasks;

- unification of the training process of pro-defence organisations and ensuring the compliance of their training with the standards associated with the Armed Forces of the Republic of Poland;

- preparation of valuable candidates for territorial and professional military service;

- granting the Passport (Biuro do Spraw Proobronnych n.d.).

2 The Corps of Cadets mentioned in the article were also treated as the initial stage of a military school, shaping predispositions, and the figure and face of future candidates for military service. Cadet Corps brought up active participants in social life, aware of their goals, rights and duties. The Corps of Cadets continued the glorious traditions of their predecessors, in particular the School of Chivalry. Similarly, in the former Military High Schools, the aim of teaching was to prepare youth for military service including, among other things, developing interests in soldiering issues and strengthening personality traits such as: sense of responsibility, honour and personal dignity, camaraderie, honesty, discipline, and even a sense of the aesthetics and care for their external appearance. Attempts have been made to ensure gradual preparation for the requirements of military service, to develop their habits of commanding small teams and to instruct them on the basic issues of drill, regulations and schooting training (Cwer 2013, pp. 42-44; Kryściak 2013, p. 60). 
The rules for obtaining a Passport consist of an introduction and two parts: the minimum program for pro-defence organizations as well as the table of training points and organisational arrangements. The introduction refers to the legal basis, assumptions and method of program implementation. The first part contains a collection of subjects and training issues necessary in cooperation with military units. The list of subjects for pro-defence organisations includes issues of tactics, communication, topography, medical training and team drill. The second part is connected with the principles of obtaining training points, rules for granting general assessment of a sub-unit/component and granting a Passport as well as notes on using the Passport. The awarding of the Passport means the certification of the components of pro-defence organisations that have passed the subjects and training issues covered by the program. The final document (the Passport certificate) proves that the component of a given organisation has achieved the objectives included in the program and the appropriate number of training points (for participation in military exercises, for example). Thus, the Passport testifies to the preparation of a component (a defense sub-unit) for cooperation with the Polish Armed Forces (Biuro do Spraw Proobronnych n.d.).

Zbigniew Leśniewski (2018, pp. 49-50) draws attention to the fact that the Armed Forces of the Republic of Poland are the main element of its defence potential, so they must have adequate defensive and offensive capabillities. This assumption also gives direction to planning and training activities in the Polish Armed Forces in peacetime. One of the tasks in this area is the reconstruction of personal reserves, while functioning of the Passport Program is a type of short military training. According to Leśniewski (2018, p. 63), this program not only allows an increase in the number of recruits, but also monitors their personal potential.

\section{Conclusions}

This research discusses security education in Poland. The study started with an introduction to the subject of education in the field of security and its evolution. Then, selected examples of types of security education in Poland were given. The concept of global education, the idea of military classes, as well as the military 
training of pro-defensive organisations within the framework of the Passport Program were covered. The following conclusions were made:

1. Types of security education implemented in Poland indicate an ever-wider etymology of security. Attempts to rebuild reserve forces made in recent years, as well as media rhetoric regarding contemporary security threats, have led some to return to a traditional, militarised understanding of security. The example of dynamically developing global education in Poland, however, shows that in security education, non-military threats and challenges such as migratory pressures are also important.

2. There is a correlation between the evolution of the understanding of security, the transformation of threats and changes in the field of educational concepts. New types of threats and challenges have forced a reorientation in the understanding of security. The answer to the wider understanding of security are further educational concepts. Focusing on defence and military-political aspects earlier in current education is increasingly widespread, including activities related to security in peacetime.

3. Promoting security education is essential for improving the functioning of the National Reserve Forces, which shoud enable the strengthening and reinforcing of operational capabilities not only in defence of the country, but also for the purpose of response to local crisis situations. Changes in security education should aim to improve its effectiveness and efficiency. Attempts to meet these challenges are still being made, as demonstrated by pilot programmes and projects involving both armed forces and the social security potential.

4. In order to improve security education, it is worth reaching for research into types of security education taling place outside of Poland. A comparison of foreign and Polish types can be helpful in determining their weaknesses and advantages. Global education, which has crystallised in Western countries, proves that foreign proposals can be successfully implemented as part of Polish solutions. 


\section{References}

Biuro do Spraw Proobronnych, n.d. O programie. [online] Available from: https://bdsp. wp.mil.pl/pl/pages/o-programie-2018-01-19-4/ [Accessed 30 Apr 2018].

Buzan, B., Wćver, O., and de Wilde, J., 1998. Security. A New Framework for Analysis. Lynne Rienner, Boulder.

Carvalho da Silva, M., (ed.), 2008. Global Education Guidelines. A Handbookfor Educators to Understand and Implement Global Education. North-South Centre of Council of Europe, Lisbon.

Cwer, A., 2013. Korpusy Kadetów - nowoczesne szkoły rycerskie II Rzeczypospolitej. In R. P. Depczyński (ed.), Edukacja patriotyczna młodzieży: Szkoła Rycerska, Korpusy Kadetów, Ogólokształcace Licea Wojskowe, Klasy Mundurowe. Sowa, Gdynia.

Decyzja nr 126/MON z dn. 30 czerwca 1999 roku w sprawie przeprowadzenia eksperymentu w zakresie edukacji obronnej młodzieży.

Depczyński, R. P., 2013. Korpus Kadetów, Liceum Wojskowe, klasy mundurowe - próba porównania. In R. P. Depczyński (ed.), Edukacja patriotyczna młodzieży: Szkoła Rycerska, Korpusy Kadetów, Ogólokształcace Licea Wojskowe, Klasy Mundurowe. Sowa, Gdynia.

Domalewska, D., 2018. Migracje a integracja imigrantów wyzwaniem edukacji dla bezpieczeństwa. In I. Urych (ed.), Edukacja dla bezpieczeństwa. Wspótczesne kategorie, Akademia Sztuki Wojennej, Warsaw.

Drabik, K., 2014. Rola edukacji w kształtowaniu bezpieczeństwa personalnego. In A. Pieczywok and K. Loranty (eds), Bezpieczeństwo jako problem edukacyjny. Akademia Obrony Narodowej, Warsaw.

Glińska, P., 2017. MON ma program dla klas mundurowych. [online] Available from: http://www.polska-zbrojna.pl/home/articleshow/22585?t=MON-ma-program-dlaklas-mundurowych [Accessed 30 Apr 2018].

Kanarski, L., Koter, M., Loranty, K., Urych, I., 2014. Klasy mundurowe. Wstępna diagnoza innowacji pedagogicznej. In S. Olearczyk and Z. Piątek (eds), Obronność w edukacji dla bezpieczeństwa. Stowarzyszenie Ruch Wspólnot Obronnych, Warsaw.

Konopka, H., 2013. Bezpieczeństwo edukacji. Edukacja dla bezpieczeństwa. Wydawnictwo Prymat Mariusz Śliwowski, Białystok.

Kryściak, T., 2013. Uczeń-Patriota. Kształcenie postaw proobronnych uczniów Liceów Wojskowych. In R. P. Depczyński (ed.), Edukacja patriotyczna młodzieży: Szkoła Rycerska, Korpusy Kadetów, Ogóloksztatcace Licea Wojskowe, Klasy Mundurowe. Sowa, Gdynia.

Kunikowski, J., 2000. Wiedza obronna: wybrane problemy edukacji dla bezpieczeństwa. Ministerstwo Obrony Narodowej, Departament Społeczno-Wychowawczy, Warsaw.

Leśniewski, Z., 2018. Szkolenie Sił Zbrojnych Rzeczypospolitej Polskiej na przykładzie edukacji wojskowej klas mundurowych, Legii Akademickiej i Programu Paszport. In I. Urych (ed.), Edukacja dla bezpieczeństwa. Wspótczesne kategorie. Akademia Sztuki Wojennej, Warsaw. 
Ministry of Foreign Affairs of the Republic of Poland, n.d., Edukacja globalna. [online] Available from: http://www.msz.gov.pl/ [Accessed 30 Apr 2018].

National Security Strategy of the Republic of Poland, 2014. National Security Bureau, Warsaw.

O'Loughlin, E. and Wegimont, L. (eds), 2003. Global Education in Europe to 2015. Strategy, policies, and perspectives. Outcomes and Papers of the Europe-wide Global Education Congress, Maastricht, The Netherlands 15th-17th November 2002. NorthSouth Centre of the Council of Europe, Lisbon.

Polish Humanitarian Action, n.d. Let's educate together. [online] Available from: https:// www.pah.org.pl/en/get-involved/for-schools/ [Accessed 30 Apr 2018].

Polska Pomoc, n.d. Edukacja globalna. [online] Available from: https://www.polskapomoc. gov.pl/ [Accessed 30 Apr 2018].

Porozumienie o współpracy między Ministerstwem Obrony Narodowej i Ministerstwem Edukacji Narodowej z dn. 26 maja 1994 roku w zakresie działalności dydaktycznowychowawczej, naukowo-badawczej i organizacyjno-logistycznej.

Quittner, K. and Sturak, K. (eds), 2008. Global Perspectives. A framework for global education in Australian schools. Education Services Australia, Australia.

Reginia-Zacharski, J., 2013. Strategia bezpieczeństwa narodowego: podejście zintegrowane. In J. Gryz (ed.), Strategia bezpieczeństwa narodowego Polski. Wydawnictwo Naukowe PWN, Warsaw.

Świniarski, J., 2011. Edukacja dla bezpieczeństwa jako najnowsza koncepcja wychowania metawojskowego i metaobronnego czasów globalizacji. In T. Szczurek (ed.), Wspótczesne trendy w edukacji dla bezpieczeństwa. Ksztatcenie - wychowanie motywowanie. Wojskowa Akademia Techniczna, Warsaw.

Urych, I., 2016. Military Class in Poland - Experiences and Perspectives. Security and Defence Quarterly, 11 (2), 112-134.

Urych, I., 2017. Students of Military Classes Concerning Selected Aspects of Poland's National Security. An Empirical Study. Security and Defence Quarterly, 17 (4), 21-47.

Urych, I., 2018. Students opinion on the academic curriculum in military classes. Security and Defence Quarterly, 18 (1), 26-44.

Zalewski, S., 2001. Polityka bezpieczeństwa państwa a edukacja obronna. Ministerstwo Obrony Narodowej, Departament Społeczno-Wychowawczy, Warsaw. 